\title{
Critical Illness in Energy Metabolism Genetic Disorder: Rhabdomyolysis, Acute Kidney Injury, Respiratory Arrest
}

\author{
E Giuliani ${ }^{1}$, F Coppi $^{2}$, V Bertolotti ${ }^{1}$, G Gorlato ${ }^{3}$, M Zavatta ${ }^{3}$, A Barbieri ${ }^{1}$
}

\begin{abstract}
In very long-chain acylCoA dehydrogenase deficiency (VLCAD), the activity of this enzyme is either reduced or absent with the inability to use long-chain fatty acids as energy substrates. A 25-year old male with VLCAD was admitted to the Emergency Department of Policlinico Teaching Hospital (Modena, Italy) for generalized weakness and oliguria, after a period of physical and mental stress and inadequate compliance to a long-chain fatty acid free diet. Laboratory tests were compatible with acute kidney injury. Seventy-two hours after admission, the subject had an episode of chest pain with elevated markers of myocardial necrosis. The rapid deterioration of muscular strength and the subsequent worsening respiratory failure necessitated ventilator support within the local Medical Intensive Care Unit. There, the patient showed a prompt normalization of respiratory parameters and a steady improvement of renal function. An inadequate compliance to lifestyle and dietary restriction in VLCAD may trigger severe and potentially lethal crisis. The in-hospital management of these patients calls for early intensive care admission as their conditions may deteriorate without warning.
\end{abstract}

Keywords: Acute kidney injury, energy metabolism genetic disorder, respiratory arrest, rhabdomyolysis, very long-chain acylCoA dehydrogenase deficiency

\section{Enfermedad Crítica por Trastorno Genético en el Metabolismo de la Energía: Rabdomiolisis, Lesión Renal Aguda, Paro Respiratorio \\ E Giuliani ${ }^{1}$, F Coppi $^{2}$, V Bertolotti ${ }^{1}$, G Gorlato $^{3}$, M Zavatta ${ }^{3}$, A Barbieri ${ }^{1}$}

\begin{abstract}
RESUMEN
En el caso de deficiencia de acylCoA deshidrogenasa de cadena muy larga (VLCAD), o bien se reduce la actividad de esta enzima, o la misma se halla ausente con la consiguiente incapacidad para utilizar los ácidos grasos de cadena larga como sustratos de energía. Un hombre de 25 años fue ingresado con VLCAD fue admitido en el Departamento de emergencia del Hospital Policlínico Docente Hospital de Modena, en Italia, a causa de presentar debilidad generalizada y oliguria, después de un período de estrés fisico y mental, y por no cumplir adecuadamente con una dieta libre de ácidos grasos de cadena larga. Las pruebas de laboratorio eran compatibles con una lesión renal aguda. Setenta y dos horas después de su ingreso, el sujeto tuvo un episodio de dolor en el pecho con marcadores elevados de necrosis miocárdica. El rápido deterioro de la fuerza muscular, y el posterior empeoramiento de la insuficiencia respiratoria requirieron el apoyo de un ventilador en la Unidad de Cuidados Médicos Intensivos. Una vez allí, el paciente mostró una pronta normalización de los parámetros respiratorios, y una constante mejoría de la función renal. Un inadecuado cumplimiento con las restricciones dietéticas y el estilo de vida en los casos de VLCAD, pueden desatar una crisis grave y potencialmente fatal. El tratamiento intrahospitalario de estos pacientes requiere un ingreso temprano en cuidados intensivos, ya que sus condiciones pueden deteriorarse sin previo aviso.
\end{abstract}

From: ${ }^{1}$ School of Anaesthesia and Intensive Care, University of Modena and Reggio Emilia, Modena, Italy, ${ }^{2}$ Department of Cardiology, Policlinico Teaching Hospital, Modena, Italy and ${ }^{3}$ School of Cardiology, University of Modena and Reggio Emilia, Modena, Italy.
Correspondence: Dr A Barbieri, School of Anaesthesia and Intensive Care, University of Modena and Reggio Emilia, Via del Pozzo 71, 41124 Modena (MO), Italy. E-mail: alberto.barbieri@unimore.it 
Palabras claves: Lesión renal aguda, trastorno genético del metabolismo de energía, paro respiratorio, rabdomiolisis, deficiencia de acylCoA deshidrogenasa de cadena muy larga (VLCAD)

\section{INTRODUCTION}

Very long-chain acylCoA dehydrogenase deficiency (VLCAD) is an autosomal genetic disorder (the gene involved is ACADVL) where the activity of the enzyme acylCoA dehydrogenase is either reduced or absent. This leads to the inability to convert long-chain fatty acids into energy (1). Symptoms include lethargy, muscle weakness, liver and cardiac hypertrophic alterations (2). Metabolic crises are triggered by excessive dietary long-chain fatty acids intake, periods of fasting (3), physical (4) and emotional (5) stress.

\section{CASE REPORT}

A 25-year old male was admitted to Policlinico Teaching Hospital (Modena, Italy), Department of Emergency for generalized weakness, oliguria and brown discoloration of the urine, after a period of physical and mental stress, associated with inadequate compliance to dietary restrictions and increased intake of foods containing long-chain fatty acids (as later reported by the patient). His medical history was positive for VLCAD, diagnosed at the age of eight by the identification of heterozygous $\mathrm{G}>\mathrm{A}$ substitution in position c. 1675 of the gene E599K on a peripheral blood sample.

Laboratory tests showed an increased level of serum urea and creatinine $(74 \mathrm{mg} / \mathrm{dL}$ and $1.74 \mathrm{mg} / \mathrm{dL}$, respectively), a reduced glomerular filtration rate (GFR $83.4 \mathrm{~mL} /$ minute) and elevated creatine phosphokinase ( $>60000 \mathrm{U} / \mathrm{l})$ compatible with exertion rhabdomyolysis and acute kidney injury, so the patient was transferred to the Department of Nephrology for haemodialysis.

In the following 72 hours, renal function steadily decreased (urea $246 \mathrm{mg} / \mathrm{dL}$, creatinine $7.52 \mathrm{mg} / \mathrm{dL}$, GFR $5.64 \mathrm{~mL} /$ minute), the subject developed worsening, generalized weakness that culminated in an episode of chest pain associated with negative T-waves in the lateral electrocardiogram (ECG) leads, without haemodynamic instability.

He was then transferred to the Department of Cardiology for follow-up. The admission transthoracic echocardiogram showed global kinesis, ejection fraction (EF) $48 \%$, in the absence of segmental dyssynergia; markers of myocardial necrosis were positive (c-TnI $0.31 \mathrm{ng} / \mathrm{mL}, \mathrm{CK}$ MB $122 \mathrm{ng} / \mathrm{mL}$ ).

The rapid deterioration of muscular strength led to respiratory failure and ultimately to complete respiratory arrest and loss of consciousness (Glasgow Coma Scale 3/15) that necessitated orotracheal intubation and transfer to Medical Intensive Care Unit for mechanical ventilation.

The patient quickly regained consciousness; after six hours of mechanical ventilation, with substantially stable respiratory parameters, a progressive improvement of respiratory muscular strength (demonstrated by the reduced need of pressure support to maintain minute volume), mechanical ventilation was definitively discontinued and the patient was extubated.

An adequate nutritional therapy was re-established that combined both parenteral and enteral feeding to meet protein and calorie goals. Six haemodialysis sessions were necessary to lower blood urea levels, then renal function progressively normalized. Histological examination of a transcutaneous renal biopsy, taken during initial assessment, showed a chronic renal structural damage as three out of five glomeruli present were sclerotic.

Regular transthoracic echocardiograms confirmed the admission global kinesis in the absence of hypertrophic alterations typical of VLCAD patients.

The patient was transferred back to the Department of Cardiology for follow-up, where a myocardial function showed an improvement. In fact, the magnetic resonance, carried out to further investigate the cardiac condition, documented a mild left ventricular hypertrophy with normal global cardiac contractility (EF 58.6\%).

During the whole hospital stay, the patient showed an inadequate level of compliance to the medical care and refused to undergo several neurological examinations. Electroencephalogram alterations were compatible with slow activity in the posterior regions (occipital and posterior temporal and parietal) and diffuse theta bursts. The patient self-discharged from the Department of Cardiology and was lost to follow-up.

\section{DISCUSSION}

The metabolic crisis in the index patient had presumably been triggered by an episode of physical and mental stress in a context of chronic lack of attention to dietary restrictions (6), as suggested by the degree of kidney damage already present at hospital admission. The inadequate compliance to nutritional requirements, as reported by the patient, with excessive intake of long-chain fatty acids (7) might explain the deterioration of the clinical conditions of the patient. This behaviour may be the real, primary cause of the series of events that ultimately led to acute kidney injury and respiratory arrest.

Electroencephalographic alterations may suggest the presence of an organic pathology underlying his distrustful behaviour, even if no clinical signs and symptoms of central nervous system involvement have been reported in VLCAD deficiency (8).

Rhabdomyolysis is a common consequence of VLCAD and the energy derangement leads to worsening muscle 
weakness and ultimately, respiratory failure. Even if cardiac alterations are a common feature of VLCAD, a reduction of global kinetics is an uncommon finding.

Very long-chain acylCoA dehydrogenase deficiency can be effectively controlled with dietary and lifestyle adjustments but, if neglected, may lead to potentially lethal consequences. The lack of compliance to medical care may have been one of the causes of the chronic cardiac and renal damage. The hospital management of patients that already suffer from VLCAD calls for early intensive care admission as their conditions may deteriorate quickly and without warning.

A specific follow-up would be necessary to monitor cardiac and renal functions and improve compliance to dietary and lifestyle restrictions.

\section{REFERENCES}

1. Spiekerkoetter U, Bastin J, Gillingham M, Morris A, Wijburg F, Wilcken B. Current issues regarding treatment of mitochondrial fatty acid oxidation disorders. J Inherit Metab Dis 2010; 33: 555-61.

2. Cox KB, Liu J, Tian L, Barnes S, Yang Q, Wood PA. Cardiac hypertrophy in mice with long-chain acyl-CoA dehydrogenase or very long-chain acyl-CoA dehydrogenase deficiency. Lab Invest 2009; 89: $1348-54$.
3. Roe CR, Wiltse HE, Sweetman L, Alvarado LL. Death caused by perioperative fasting and sedation in a child with unrecognized very long chain acyl-coenzyme A dehydrogenase deficiency. J Pediatr 2000; 136: $397-9$.

4. Behrend AM, Harding CO, Shoemaker JD, Matern D, Sahn DJ, Elliot DL et al. Substrate oxidation and cardiac performance during exercise in disorders of long chain fatty acid oxidation. Mol Genet Metab 2012; 105: $110-5$.

5. Merinero B, Pascual Pascual SI, Pérez-Cerdá C, Gangoiti J, Castro M, Garcia MJ et al. Adolescent myopathic presentation in two sisters with very long-chain acyl-CoA dehydrogenase deficiency. J Inherit Metab Dis 1999; 22: 802-10.

6. Tucci S, Flögel U, Sturm M, Borsch E, Spiekerkoetter U. Disrupted fat distribution and composition due to medium-chain triglycerides in mice with a $\beta$-oxidation defect. Am J Clin Nutr 2011; 94: 439-49.

7. Costa CG, Dorland L, de Almeida IT, Jakobs C, Duran M, Poll-The BT. The effect of fasting, long-chain triglyceride load and carnitine load on plasma long-chain acylcarnitine levels in mitochondrial very long-chain acyl-CoA dehydrogenase deficiency. J Inherit Metab Dis 1998; 21: 391-9.

8. Oey NA, Ruiter JP, Ijlst L, Attie-Bitach T, Vekemans M, Wanders RJ et al. Acyl-CoA dehydrogenase 9 (ACAD 9) is the long-chain acyl-CoA dehydrogenase in human embryonic and fetal brain. Biochem Biophys Res Commun 2006; 346: 33-7. 